\title{
Glacier lake outburst flood disasters in China
}

\author{
Ding YongJian AND LiU Jingshi \\ Lanzhou Institute of Glaciology and Geocryology, Academia Sinica, 730000 Lanzhou, China
}

\begin{abstract}
Floods caused by outbursts from lakes dammed either by end moraines or by glaciers are the most important disasters related to glaciers in China. The former occur mainly in Tibet, and the latter in Xinjiang Province. Exceptionally large outbursts from lakes dammed by end moraines have been reported 19 times since 1935 amd 30 outbursts from glacier-dammed lakes have been recorded since 1956. Outbursts from lakes dammed by end moraines are closely associated with ice avalanches, and $79 \%$ of all dam failures occur during July to August when ice avalanches are frequent. Outbursts from glacier-dammed lakes often occur in years of very high air temperature, and $63.3 \%$ of all failures are between August and September when the storage capacities of glacier lakes reach their limit. Whether or not the end moraine-dammed lakes are of potential danger depends on the flow of the glacier that feeds the lake and the vertical distance between the terminus of the glacier and the level of the lake. The frequency of periods of outbursts from glacierdammed lakes corresponds to the periods of glacier advance. During the last 160 years, three periods of frequent outbursts from glacier-dammed lakes have occurred. Their duration has been 20 to 30 years and the interval between them about 40 years. The frequency of glacier lake outbursts could increase early in the next century if glaciers advance and dam up new marginal lakes in response to a cold period since 1940.
\end{abstract}

\section{INTRODUGTION}

Glacier lakes of various sizes and shapes are widely distributed in the western alpine regions of China where the present glaciers are situated. Catastrophic outbursts from glacier lakes, produced by various causes, occur frequently in these regions. Most of them have been ignored as they happened in untraversed regions. However, the known catastrophic outbursts from glacier lakes, as well as meltwater floods and debris flows, have caused severe damage with respect to life and property, farmland, water conservancy, communications, transportation, etc. For example, catastrophic outbursts from glacier lakes in the Himalaya in 1954 inundated hundreds of residential areas, including the cities of Xigaze, Gyangze and Yadong and a number of farmlands, water conservancy and traffic facilities. After the Damenhai glacier lake outburst in Gongbogyernde County in 1964, the flood rushed down with the speed of $10 \mathrm{~m} \mathrm{~s}^{-1}$ from $5120 \mathrm{~m}$ a.s.l., headed direct to the mouth of a channel at about $3400 \mathrm{~m}$ a.s.l. and lashed at the side of the Niyang River. The debris flow piled up to form a dam in the river valley. The dam was $20 \mathrm{~m}$ high, $850 \mathrm{~m}$ long and $150 \mathrm{~m}$ wide at the top, and it obstructed the river for about ten hours. The flood destroyed the Sichuan-Xinzang highway, cut off the traffic for 20 days, inundated most of four pasturelands and washed away trees on both sides of the gully. In 1981, the Zhongzangbo glacier lake burst and debris flow in Nyalam County smashed the highway for $50 \mathrm{~km}$ between the outlet of Zongzangbo gully and the
Sun Kosi power station in Nepal. In 1982 the Jinco glacier lake outburst submerged eight villages and a large number of fields, and more than 1600 livestock were killed. In 1984, the Erkuran glacier lake of the Gez riverbasin burst, and the debris flow blocked the Gez River and damaged the China-Pakistan highway and a bridge.

With the development of communication, transportation, farming and animal husbandry in the west of China, the disasters which are brought about by outburst floods and debris flows have seriously affected life and property and the economic reconstruction of these regions. Therefore, it is important and urgent to understand the distribution of the dangerous glacier lakes, in order to study the causes of their outbursts and to promote preventive measures. Hence, catastrophic outbursts from glacier lakes have been brought to the attention of scientists, and various types of outburst disasters have been reported and studied during the past ten years (Hewitt, 1982; Lai, 1984; Lu and Li, 1986; Xu, 1987; Xu and Feng, 1988, 1989).

\section{TYPES AND DISTRIBUTION OF THE GLACIER LAKES}

Two types of potentially dangerous glacier lakes are known in China. One is the lake dammed by an end moraine and the other is the lake dammed by a glacier. Outbursts from lakes dammed by end moraines occur mainly in the Himalaya, the middle and eastern 


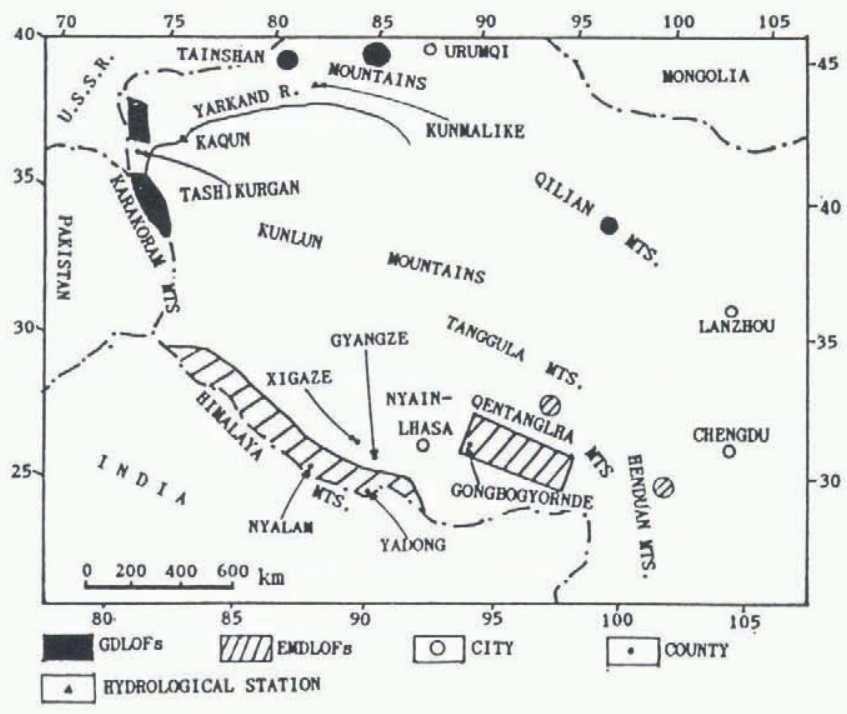

Fig. 1. Distribution of floods from glacier-dammed lakes (GDLOFs) and floods from lakes dammed by end moraines (EMDLOFs).

Nyainqentanglha mountains and sections of the Hengdaun mountains in China (Fig. 1). Up to the present, outbursts from lakes dammed by end moraines happen most frequently in the middle section of the Himalaya (Table 1). Nineteen outbursts from lakes dammed by end moraines have been investigated since 1935. The dams of the end-moraine lakes are made up of various terminal moraines that have formed since the Little Ice Age, of which the youngest moraine lakes, which are close to the present glaciers, are the most dangerous.

Outbursts from glacier-dammed lakes are mainly scattered over the Karakoram mountains, the Pamir and the western Tien Shan mountains in the west of China (Fig. 1). The famous glacier-dammed lakes, Taramkangri and Kyagar, are situated at the upper reaches of the Yarkand River in the Shaksgam valley. Taramkangri and Kyagar Glaciers, both located on northern slopes of the Karakoram mountains, extend to the Shaksgam valley and have dammed up two lakes, $5 \mathrm{~km}$ apart (Table 2). These two glacier lakes have burst repeatedly, as recorded at Kaqung hydrological station at the outlet of the Yarkand River since 1954. Up to now, 30 outbursts from glacier-dammed lakes have been recorded since 1956, of which there have been 18 in the Yarkand River, Karakoram mountains, six in the Kunmalike River, Tien Shan mountains, three in the Sikeshu River, Tien Shan mountains (Lai, 1984), two in the Gez River, Pamir and one in the Qilian mountains.

Glacier lakes liable to outbursts are distributed mainly over the mountainous border regions of Qinghai-Xizang Plateau where there are frequent neotectonic movements and high altitudes. The greatest concentration of outbursts from lakes dammed by end moraines is found in the middle Himalaya around Mount Everest. The region where outbursts from glacier-dammed lakes occur frequently is in the Karakoram where the second highest

Table 1. History of outbursts from lakes dammed by end moraines

Lake Longitude Latitude Date $\begin{gathered}\text { Flood }(F) \text { or } \\ \text { debrisflow }(D)\end{gathered}$ Cause Mountain/river system

Zhanlonba

\section{Taraco}

Qubixiama

Sangwang

Hailuogou

$\begin{array}{ll}\text { Zhangzangbo } & 85^{\circ} 51^{\prime} 25^{\prime \prime} \\ \text { Longda } & 85^{\circ} 00^{\prime} 25^{\prime \prime} \\ \text { Gelhaipu } & 87^{\circ} 48^{\prime} 31^{\prime \prime} \\ \text { Damenhai } & 93^{\circ} 09^{\prime} 15^{\prime \prime} \\ \text { Ayaco } & 86^{\circ} 29^{\prime} 33^{\prime \prime}\end{array}$

\section{Bugyai}

Zari

Zirema

Jinco

Gule $86^{\circ} 07^{\prime} 54^{\prime \prime}$

$85^{\circ} 02^{\prime} 24^{\prime \prime}$

$90^{\circ} 40^{\prime} 00^{\prime \prime}$

$102^{\circ} 00^{\prime} 00^{\prime \prime}$

$28^{\circ} 17^{\prime} 29^{\prime \prime}$

$27^{\circ} 42^{\prime} 30^{\prime \prime}$

$28^{\circ} 24^{\prime} 54^{\prime \prime}$

$29^{\circ} 32^{\prime} 00^{\prime \prime}$

$28^{\circ} 10^{\prime} 38^{\prime \prime}$

$28^{\circ} 24^{\prime} 46^{\prime \prime}$

$27^{\circ} 57^{\prime} 50^{\prime \prime}$

$29^{\circ} 56^{\prime} 20^{\prime \prime}$

$28^{\circ} 20^{\prime} 49^{\prime \prime}$

$94^{\circ} 48^{\prime} 36^{\prime \prime}$

$90^{\circ} 48^{\prime} 30^{\prime \prime}$

$86^{\circ} 03^{\prime} 54^{\prime \prime}$

$87^{\circ} 38^{\prime} 29^{\prime \prime}$

$94^{\circ} 30^{\prime} 00^{\prime \prime}$

$31^{\circ} 46^{\prime} 20^{\prime \prime}$

$28^{\circ} 22^{\prime} 50^{\prime \prime}$

$28^{\circ} 04^{\prime} 36^{\prime \prime}$

$28^{\circ} 11^{\prime} 39^{\prime \prime}$

$29^{\circ} 30^{\prime} 00^{\prime \prime}$
28 August 1935

21 September 1964

26 September 1964
1902

10 June 1940

16 July 1954

July 1955

July 1966

30 August 1976

July 1964

11 July 1981

25 August 1964

15 August 1965

17 August 1969

18 August 1970

F/D

23 July 1972

24 June 1981

11 July 1981

27 August 1982

15 July 1988

F
Nyainqentanglha/Yiongzhangbo River

IA* Himalaya/Poiqu River

IA Himalaya/upper Kangma River

IA Himalaya/upper Nyangqu River

Hengdaun/upper Yalong River

Himalaya/Poiqu River

IA Himalaya/Trisuli River

IA Himalaya/Puqu River

IA Nyainqentanglha/Niyang River

IA Himalaya/Pumqu River

IA

IA

F/D IA

F/D IA

D IA

D IA
Nyainqentanglha/Nujiang River

Himalaya/Pumqu River

Himalaya/Poiqu River

Himalaya/Pumqu River

Nyainqentanglha/Berongzhongbu

River

$\mathrm{IA}^{*}=$ Ice avalanche into the lake. 
Ding Yongjian and Liu Fingshi: Glacier lake outbursts

Table 2. Data for Taramkangri and Kyagar Lakes (Liu Finshi, 1988, unpublished)

\begin{tabular}{|c|c|c|c|c|c|c|}
\hline Lake & Altitude & Length & Width & Volume & $\begin{array}{c}\text { Maximum } \\
\text { depth }\end{array}$ & $\begin{array}{c}\text { Length of } \\
\text { barrier }\end{array}$ \\
\hline & m a.s.l. & $\mathrm{km}$ & $\mathrm{m}$ & $10^{8} \mathrm{~m}^{3}$ & $\mathrm{~m}$ & $\mathrm{~km}$ \\
\hline
\end{tabular}

\begin{tabular}{lrrrrrrl}
\hline \multirow{2}{*}{ Kyagar } & 4836 & 4.93 & 398 & 0.60 & 85 & 1.5 & $1976-87$ \\
& 4900 & 9.48 & 638 & 3.15 & 155 & & postglacial maximum \\
\multirow{2}{*}{ Taramkangri } & 4650 & 5.25 & 500 & 0.96 & 70 & 3.8 & $1976-87$ \\
& 4672 & 7.41 & 610 & 1.92 & 90 & & postglacial maximum
\end{tabular}

peak in the world, Mount Qogir, is located. Similar lakes in China are mostly situated between 4500 and $5200 \mathrm{~m}$ a.s.l. Their areas are under $3 \mathrm{~km}^{2}$ for the largest ones and only $0.01 \mathrm{~km}^{2}$ for the smallest ones.

\section{INVESTIGATIONS OF OUTBURSTS FROM GLACIER-DAMMED LAKES}

The mechanism of an outburst is complicated, but the external factors that trigger it are obvious. When a glacier lake stores water, its level rises with increasing glacier ablation. Consequently, outbursts from glacier-dammed lakes often occur in years of the highest air temperature (Fig. 2). The volume of most of the outbursts is between 1000 and $3000 \mathrm{~m}^{3} \mathrm{~s}^{-1}$. The probable reason why four of the floods reached peaks between 5000 and $6000 \mathrm{~m}^{3} \mathrm{~s}^{-1}$ is because two ice-dammed lakes, Taramkangri and Kyagar, burst at the same time. Three of the four largest floods in the Yarkand River, and all floods in the Kunmalike River, happened between 20 August and 30 September, which is over a month later than the maximum ablation period in July. Failure of dams happens mostly between 20 August and 30 September

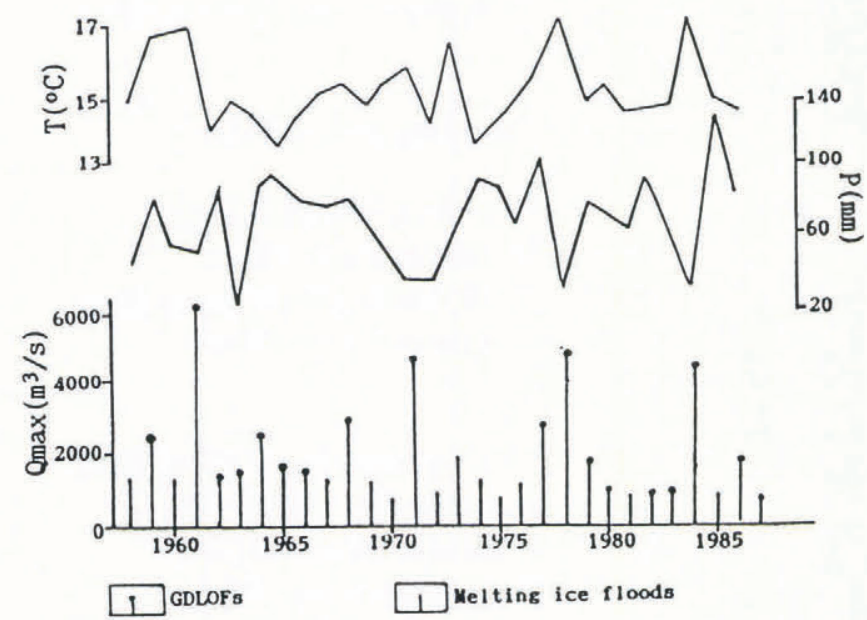

Fig. 2. Peak discharge of glacier outbursts of the Yarkand River at Kaqun Station, mean air temperature in summer and annual precipitation at Tashikurgan Station $(3090 \mathrm{~m}$ a.s.l.). GDLOFs are floods from glacier-dammed lakes. when the storage capacity of the glacier lakes reaches a maximum (Table 3). It might be postulated that the catastrophic outbursts from glacier-dammed lakes can be predicted on the basis of weather forecasts, when satellite images show that the lakes have reached their maximum area.

In general, an ice dam is not frozen to its bed, water from the lake does not flow over the dam and the lake drains through subglacial channels. After the outburst, the dam forms again.

\section{POTENTIALLY DANGEROUS END-MORAINE DAMMED LAKES}

An end-moraine dam is different from a marginal glacier dam. The latter is composed of ice which easily melts and cracks, but the former is composed of till of various sizes

Table 3. Timing of outbursts from glacier-dammed lakes and outbursts from lakes dammed by end moraines

Date Outbursts from glacier- Outbursts from lakes dammed lakes dammed by end moraines

Number $\quad \% \quad$ Number $\%$

\begin{tabular}{|c|c|c|c|c|}
\hline July to & 7 & 23.3 & 11 & 57.9 \\
\hline 20 August & & & & \\
\hline $\begin{array}{l}20 \text { August to } \\
30 \text { September }\end{array}$ & 14 & 46.7 & 6 & 31.6 \\
\hline after 30 September & $\mathrm{r} 7$ & 23.3 & 0 & 0 \\
\hline before 1 July & 2 & 6.7 & 2 & 10.5 \\
\hline total & 30 & 100 & 19 & 100 \\
\hline
\end{tabular}

\begin{tabular}{lrrrr} 
July & 2 & 6.7 & 8 & 42.1 \\
August & 11 & 36.7 & 7 & 36.9 \\
September & 8 & 26.6 & 2 & 10.5 \\
others & 9 & 30.0 & 2 & 10.5 \\
total & 30 & 100 & 19 & 100 \\
\hline
\end{tabular}


Table 4. Glacier lake inventory in the Poiqu and Pumqu basins (Liu, C. H. and Sharmal, 1988)

\begin{tabular}{|c|c|c|c|c|c|c|c|c|c|}
\hline \multirow{3}{*}{$\begin{array}{l}\text { Type of } \\
\text { lake }\end{array}$} & \multicolumn{2}{|c|}{ Lakes } & \multicolumn{2}{|c|}{ Lakes } & \multicolumn{2}{|c|}{ Lakes } & \multirow{2}{*}{$\begin{array}{l}\text { Mean } \\
\text { area }\end{array}$} & \multirow{2}{*}{$\begin{array}{l}\text { Mean } \\
\text { volume }\end{array}$} & \multirow{2}{*}{$\begin{array}{l}\text { Mean } \\
\text { depth }\end{array}$} \\
\hline & number & $\begin{array}{l}\% \text { of } \\
\text { total }\end{array}$ & area & $\begin{array}{l}\% \text { of } \\
\text { total }\end{array}$ & volume & $\begin{array}{l}\% \text { of } \\
\text { total }\end{array}$ & & & \\
\hline & & & $\mathrm{km}^{2}$ & & $\mathrm{~km}^{3}$ & & $\mathrm{~km}^{2}$ & $10^{8} \mathrm{~m}^{3}$ & $\mathrm{~m}$ \\
\hline cirque & 86 & 31.6 & 6.56 & 11.7 & 0.066 & 4.4 & 0.076 & 0.77 & 10 \\
\hline rough valley & 47 & 17.3 & 12.47 & 22.2 & 0.312 & 20.7 & 0.265 & 6.63 & 25 \\
\hline $\begin{array}{l}\text { end moraine- } \\
\text { dammed }\end{array}$ & 139 & 51.2 & 37.09 & 66.1 & 1.124 & 74.9 & 0.267 & 8.09 & 30 \\
\hline total & 272 & & 56.11 & & 1.501 & & & & \\
\hline
\end{tabular}

and is normally much more stable than the ice dam. An inventory of existing glacier lakes of the Pumqu and Poiqu Rivers in the Himalaya was made by a SinoNepalese expedition investigating glacier lake outbursts in the Himalaya in 1988 (Table 4). Only $3.7 \%$ of the total number of the glacier lakes and $7.2 \%$ of the end morainedammed lakes are dumping glacier lakes.

The following morphological features characterize a dangerous end-moraine dam: it has a closed lake basin, a dam height over $80 \mathrm{~m}$, a ratio of dam height to top width less than 0.6, an angle of slope of the outside of the dam of about $23^{\circ}$ and a water depth at the dam over one-third of its height ( $\mathrm{Xu}$ and Feng, 1989). Further, the dam contains an ice core that may reduce its stability. However, the static pressure maintained by the lake is still not high enough to burst the dam without an additional external action being exerted. The investigated outbursts from lakes dammed by end moraines were all induced by ice avalanches that came from the glaciers feeding the lakes. In each case, an ice avalanche dropped suddenly into the lake; swift and violent waves travelled down the lake, creating breaches in the dam. Because an ice avalanche is associated closely with melting of ice, periods of maximum ablation also are those of frequent ice avalanches. Hence, $79 \%$ of all failures of the dams occur during the hottest months of July and August (Table 3).

Whether or not end moraine-dammed lakes are dangerous depends on the flow of the glacier that feeds the lake. In an advancing glacier, the glacier tongue is so steep that many cracks develop and ice avalanches are easily produced. Ice avalanches falling into the lake will create waves of huge surging pressure to the dam wall. On the other hand, when a glacier extends down into the lake along a gentle slope, ice sliding into the lake creates small pressures to the dam wall. The areas of the glaciers above the end-moraine lakes are usually between 1.5 and $5.5 \mathrm{~km}^{2}$ and the glaciers are between 1 and $4 \mathrm{~km}$ long. The glacier tongue is generally located in a steep depression or a valley, with the lower part in an

Table 5. Comparison of dangerous and stable moraine-dammed lakes in the Himalaya

\begin{tabular}{|c|c|c|c|c|c|c|c|}
\hline & \multicolumn{3}{|c|}{ Lake } & \multicolumn{4}{|c|}{ Glacier } \\
\hline & altitude & area & $\begin{array}{l}\text { distance to } \\
\text { glacier }\end{array}$ & $\begin{array}{l}\text { terminus } \\
\text { elevation }\end{array}$ & length & area & $\begin{array}{c}\text { average } \\
\text { slope }\end{array}$ \\
\hline & $\mathrm{m}$ a.s.l. & $\mathrm{km}^{2}$ & $\mathrm{~m}$ & $\mathrm{~m}$ a.s.l. & $\mathrm{km}$ & $\mathrm{km}^{2}$ & $\%$ \\
\hline \multicolumn{8}{|l|}{ Dangerous } \\
\hline Jinco & 5350 & 0.550 & 0 & 5350 & 3.8 & 3.24 & 34.4 \\
\hline Coxar & 5420 & 0.660 & 0 & 5440 & 2.8 & 3.43 & 23.6 \\
\hline Ahamachimaico & 5470 & 0.565 & 0 & 5200 & 3.8 & 1.66 & 15.7 \\
\hline Paquco & 5300 & 0.506 & 0 & 5320 & 4.0 & 5.4 & 17.8 \\
\hline \multicolumn{8}{|l|}{ Stable } \\
\hline Dongyico & 4980 & 0.040 & 600 & 5800 & 3.1 & 5.25 & 18.5 \\
\hline Zongbuxan No. 13 & 5320 & 0.198 & 0 & 5360 & 12.5 & 24.39 & 7.2 \\
\hline Kada No. 13 & 5570 & 0.191 & 300 & 5460 & 8.0 & 14.49 & 11.0 \\
\hline Zongbuxan No. 2 & 5670 & 0.072 & 300 & 5750 & 5.0 & 4.96 & 5.1 \\
\hline
\end{tabular}


extended state, so that cracks tend to form. Thus, it is important to understand recent developmental and morphological features of the glacier to determine whether an end moraine-dammed lake is of potential danger. Table 5 shows some typical end morainedammed lakes in the middle Himalaya of China. It can be seen that the potentially dangerous lakes have a larger lake area and a smaller glacier area, a shorter distance from the glacier terminus to the lake and a steeper angle of slope to the glacier tongue than the stable, nondangerous lakes.

\section{LONG-TERM CHANGES IN FREQUENCY OF OUTBURSTS FROM GLACIER-DAMMED LAKES IN CHINA}

Liu (1980) presented results on changes of climate and glaciers in the Karakoram region based on tree-ring statistics (Fig. 3, lower part). Three cold periods (C1, C2, C3) since 1740 correspond to periods of glacier advance (A1, A2, A3). Plotting the number of outbursts from lakes dammed by end moraines in China and the recorded and investigated outbursts from glacier-dammed lakes in the Karakoram mountains, we find that periods of frequent outbursts from glacier-dammed lakes are identical with periods of glacier advance (Fig. 3). Figure 3 shows the total number of outbursts from glacier-dammed lakes in the Karakoram over a period of ten years, as reported by Hewitt (1982) and by the hydrological station, for the southern and northern slopes, respectively. There have been 71 reported outbursts from glacier-dammed lakes in the Karakoram region from the beginning of the 19th century to the present. The periods when outbursts from
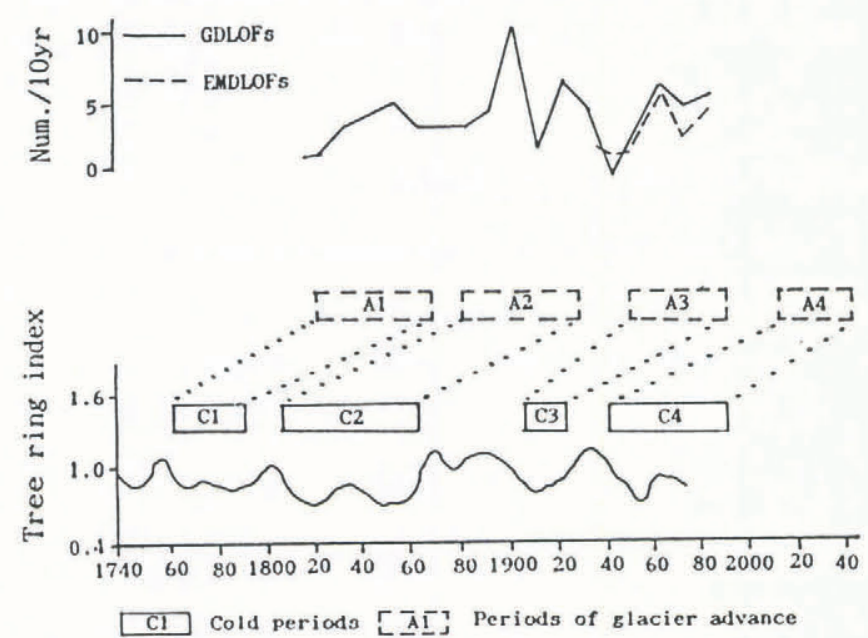

$\mathrm{C} 1=1760-1790 \quad \mathrm{C} 2=1805-1865 \quad \mathrm{C} 3=1906-1923 \quad \mathrm{C} 4=1940-1990$ $A_{1}=1820-1870 \quad A_{2}=1880-1930 \quad A_{3}=1950-1990 \quad A 4=$ Next century

Fig. 3. Comparison between changes in climate, glacier advance and occurrence of outbursts from glacier-dammed lakes (GDLOFs) and from lakes dammed by end moraines (EMDLOFs). glacier-dammed lakes occurred most frequently were $1830-50,1890-1920$ and $1960-80$, which correspond to periods of glacier advance in 1820-70 (A1), 1880-1930 (A2) and 1950-90 (A3), respectively. This indicates that colder periods give rise to periods of glacier advance, which, after the response time-lag imposed by the glacier dynamics, cause an increase in the number of glacier dams and hence an increase in the number of outburst floods. For the ice-dammed lakes of Iceland, Thorarinsson (1939) came to a similar conclusion. It can also be shown that outbursts from glacier-dammed lakes occur frequently for about 20 to 30 years and with intervals between this activity of about 40 years. Therefore, if glacier advances take place at the beginning of the next century, in response to the cold period since 1940, frequent outbursts from glacier lakes may be expected.

\section{REFERENCES}

Hewitt, K. 1982. Natural dams and outburst floods of the Karakoram Himalaya. International Association of Hydrological Sciences Publication 138 (Symposium at Exeter 1982 - Hydrological Aspects of Alpine and High-Mountain Areas), 259-269.

Lai Zuming. 1984. Characteristics of glacial flood example of rivers in Xinjiang. 7. Glaciol. Geocryol., 6(2), 45-52. [In Chinese with English abstract.]

Liu, C. H. and C. K. Sharmal. 1988. Report on first expedition to glacier and glacier lakes in the Pumqu and Poiqu river basins, Xizang (Tibet), China. Beijing, Science Press.

Liu Guangyuan. 1980. The climate of the Batura Glacier and its adjacent areas. In Lanzhou Institute of Glaciology and Geocryology. Professional papers on the Batura Glacier, Karakoram mountains. Beijing, Science Press, 107-108.

Lu Ruren and Li Deji. 1986. Debris flow induced by ice lake burst in the Tangbulang gully, Gongbujiangda, Xizang (Tibet). F. Glaciol. Geocryol., 8(1), 61-71. [In Chinese with English abstract.]

Thorarinsson, S. 1939. The ice dammed lakes of Iceland with particular reference to their values as indicators of glacier oscillations. Geogr. Ann., 21(3-4), 216-242.

Xu Daoming. 1987. Characteristics of debris flow caused by outburst of glacial lakes on the Boqu River in Xizang, China. 7. Glaciol. Geocryol., 9(1), 23-34. [In Chinese with English abstract.]

Xu Daoming and Feng Qinghua. 1988. Studies on catastrophes of glacial debris flow and glacial lake outburst floods in China. 7. Glaciol. Geocryol., 10(3), 284-289. [In Chinese.]

Xu Daoming and Feng Qinghua. 1989. Characteristics of dangerous glacier lakes and their outburst, Tibet, Himalaya mountains. Acta Geographica Sinica, 44(4), 343-345.

The accuracy of references in the text and in this list is the responsibility of the author/s, to whom queries should be addressed. 